\title{
TRADE POLICY UNDER IMPERFECT COMPETITION: THE ECONOMICS OF RUSSIAN ROULETTE**
}

\author{
BY
}

\author{
STEVEN BRAKMAN AND CHARLES VAN MARREWIJK*
}

Key words: Imperfect Competition, Trade Policy, Protectionism

\section{INTRODUCTION}

The world is changing at a rapid pace, and so is its economic structure. Europe is producing goods and services, such as compact disc players, computer games and financial derivatives that did not exist 40 years ago. Moreover, we export and import these and other goods and services to and from countries that did not even exist 7 years ago, such as Estonia of the Ukraine. We have witnessed the impressive rise to wealth of Japan, now followed by other countries in South East Asia, such as Singapore, South Korea, Hong Kong, and Taiwan. At the same time, some countries in South America or Eastern Europe did not perform very well, while still others, mainly in Africa, actually become impoverished over time. The way our companies are organized has changed equally fast, such that 'just in time delivery' is now a household word. By the time everyone is used to communicate by fax machines they are becoming largely obsolete through the introduction of more efficient electronic mail systems. It now looks like many less developed countries can basically skip the step of ordering copper or glass telephone cables because telecommunication satellites make wireless telephone calls to and from almost any place on earth possible. For some industries these rapid changes mean that their competitiveness on the global market diminishes to such an extent that survival becomes almost impossible; the history of the textile industry in a number of European countries serves as an example. Instead of facing the competitive challenge some industries have responded with a continued demand for protection, provided to some extent by their politicians. This has been called 'the senile industry argument for protection' or, less derogatory, 'New Protectionism' (see Magee et al., 1989, chapter 17 for a survey).

There are also other reasons for protectionism. Indeed, it is argued that protectionist measures are required to counter the more covert trade policies of the

* University of Groningen and Erasmus University Rotterdam, respectively.

* We would like to thank, without implicating, Martin Fase, Harry Garretsen, Catrinus Jepma, Simon Kuipers, Ger Lanjouw, Teun Schmidt, Albert de Vaal, and Jean-Marie Viaene for stimulating conversations and useful suggestions. We thank Thijs Knaap for excellent research assistance. Please send all correspondence to: Steven Brakman, University of Groningen, Dept. of Economics, P.O. Box 800, 9700 AV Groningen, The Netherlands. tel: *31-50-3633746; fax: *31-50-3637337; email: s.brakman@eco.rug.nl 
newly industrializing countries. At the beginning of 1995 the United States, after long and fruitless debates with China, announced the levying of $100 \%$ import tariffs on selected goods to coerce China to better fulfill its obligations in the realm of protecting intellectual property rights. Soon after the announcement China gave in. In May 1995 the United States announced the levying of 100\% import tariffs on selected automobiles imported from Japan to coerce Japan to grant the United States better access to the Japanese automobile and car parts market. After many days of frantic negotiating Japan and the United States reached an agreement only a few hours before the announced tariffs would be imposed. President Clinton said the agreement was 'a great step to free trade throughout the world.' ${ }^{1}$ Power politics pays off, or so it seems. In both cases the quality and verifiability of the reached agreement is questionable. The Chinese do not really seem to be interested in protecting American property rights, but did close a few small plants producing illegal compact discs. In the car conflict between Japan and the United States Mickey Kantor, the United States trade representative, emphasized that it is a voluntary agreement and said that 'there are no obligations between governments, American trade laws do not apply, and the numbers can change if economic circumstances do.' 2 The countries of the European Union (especially France) have objected to the bilateral nature of the agreement (in contradiction with World Trade Organization rules), which threatens to put other countries at a disadvantage in exporting cars to Japan. Moreover, if the Americans are serious about boosting car exports to Japan they should put the steering wheel on the right hand side, as some US car manufacturers now start to do.

Should Europe follow the power politics lead of the United States in trade policy, or should it try to shield its producers from the cold winds of international competition in a more covert or subtle way, as Japan and other successful nations are repeatedly accused of doing ${ }^{3}$. This essay addresses three specific questions raised by the editors of De Economist:

1. What should be the structure of European trade policy in a world where international trade is increasingly dominated by intra-industry trade and multinational enterprises?

2. How should Europe react to trade impediments imposed by other economic entities, such as the United States or Japan?

3. How should Europe react to low-cost competition from other parts of the world, such as Eastern Europe or South East Asia?

\footnotetext{
1 NRC Handelsblad, 29 June, 1995 (in Dutch).

2 See footnote 1.

3 Some myths on these covert ways play a role here, testifying Bhagwati's (1988, p. 69) anecdotal evidence on the difficulty Holland had in exporting tulip bulbs to Japan because the Japanese insisted on checking them by cutting the stems vertically down the middle. In reality, however, the problem was that the bulbs had to be in quarantine for one year (Dujat, 1995).
} 
These broad questions touch upon a number of interesting aspects of international trade theory and policy. Adequately addressing these issues thus requires us to draw upon a plethora of theoretical arguments, practical observations and empirical research. Throughout this essay the reader should have one important premise in mind: Europe is special, but not too special. Europe is special in the sense that it has its own economic, social and cultural history, its own structural developments, etc. These issues are addressed below to a limited extent. Europe is, however, not special in the sense that it requires an entirely different economic analysis. There is no sharp distinction between trade theory in general and European trade theory. If an increase in intra-industry trade points to an increase in the importance of imperfect competition in general, this also holds for Europe to the extent that Europe's level of intra-industry trade increases. If relatively autarkic trade policies prove to be disastrous for the Soviet Union, Argentina and North Korea, these policies can hardly be expected to be a blessing for the European Union.

The first question above presupposes that international trade is increasingly dominated by intra-industry trade and multinational enterprises. Section 3 of this paper shows that this is indeed the case. The conclusion derived from this observation is that imperfect competition is becoming ever more important in the world trading system. Thus, we answer the three questions raised above in the light of the increased importance of imperfect competition in a dynamically changing world economic system, see sections 4-6. To contrast our findings with the conventional wisdom of trade policy we start our analysis in section 2 below by briefly discussing the seemingly small costs of protection in a static framework of perfect competition. These seemingly low costs explain to some extent why protectionism exists and why many policy advisers again want to install protectionist measures as a relatively cheap policy instrument for a variety of economic and non-economic objectives.

\section{STANDARD ANALYSIS OF PROTECTIONISM AND INTERNATIONAL INTERDEPENDENCE}

\subsection{Increasing International Interdependence}

World production has grown enormously since World War II. World trade, however, has grown even faster. Europe is exporting and importing an ever increasing share of its products to and from other countries, be they far away or close by. This is illustrated in Table 1, showing that in just two decades the share of world production destined for other countries has increased by about $50 \%$ (from $10.1 \%$ of GNP in 1970 to $15.4 \%$ of GNP in 1991). ${ }^{4}$ In 1991 an impressive share

4 Note that Table 1 suffers from the usual consistency problem in that world imports are larger than world exports. 
TABLE 1 - INCOME AND TRADE

\begin{tabular}{lcrrr}
\hline Country & $\begin{array}{l}\text { Exports } \\
1991(\$ \mathrm{~b})\end{array}$ & $\begin{array}{l}\text { Imports } \\
1991(\$ \mathrm{~b})\end{array}$ & \multicolumn{2}{c}{ Exports/GNP } \\
\cline { 5 - 5 } & & & $1970 \%$ & $1991 \%$ \\
\hline India & 17.7 & 20.4 & 3.8 & 7.8 \\
China & 72.1 & 63.8 & 1.8 & 19.5 \\
Indonesia & 29.0 & 25.9 & 12.4 & 24.9 \\
Mexico & 27.1 & 38.2 & 3.4 & 9.6 \\
Brazil & 31.6 & 23.0 & 7.6 & 7.6 \\
S. Korea & 71.7 & 81.3 & 9.0 & 25.3 \\
EC-12 & $1,366.0$ & $1,447.1$ & 16.5 & 22.4 \\
$\quad$ Spain & 60.1 & 93.1 & 6.3 & 11.4 \\
U.K. & 185.1 & 210.0 & 18.2 & 21.1 \\
$\quad$ Germany & 401.8 & 387.9 & 18.9 & 22.4 \\
Canada & 124.8 & 117.6 & 22.6 & 24.4 \\
U.S. & 397.7 & 506.2 & 4.3 & 7.1 \\
Japan & 314.4 & 234.1 & 9.5 & 9.4 \\
World & $3,336.6$ & $3,508.2$ & 10.1 & 15.4 \\
\hline
\end{tabular}

Source: Markusen et al. (1995). Note that EC-12 imports and exports include intra-EC trade, see also footnote 5 .

of total world trade, some $40 \%$, was accounted for by the 12 members of the European Union, much of which is intra-European Union trade. ${ }^{5}$ Indeed, in that same year Germany was the world's largest exporter. The European level of international interdependence is high and has even increased. Of the many causes of this rise in international interdependence we just want to mention the general decrease of relative transportation costs, the emergence of regional trading blocks (such as the European Union or ASEAN), and the completion of many successful GATT multilateral trade negotiation rounds. In view of the increased regional cooperation (the expansion of the European Union and the emergence of NAFTA) together with the recent successful completion of the Uruguay Round and the founding of the World Trade Organization, we can expect a continuing rise in the world level of international interdependence. With respect to the costs of managed trade or protectionism one would expect, solely based on the high and rising level of international interdependence, high and rising costs of trade protection. $^{6}$

5 Some 70 percent of European trade was intra-European Union trade.

6 This follows from the obvious observation that if international trade is absent, protection is (almost) without welfare consequences and if all trade is international trade, the consequences are maximal. 


\subsection{The Small Costs of Protection}

Many studies on the welfare effects of trade liberalization concentrate on the European Union, which arguably serves as an example of the largest and most successful economic integration scheme in the world. In terms of institutional widening and deepening no other integration scheme is equally successful. To a large extent the growth of trade of the European Union is intra-European Union trade rather than trade with the rest of the world, partly due to the remarkable growth of non-tariff protection directed at third countries (Winters, 1993). This increase of non-tariff protection has often been excused by pointing at 'dumping' by producers from the Far East, the United States or Japan. Anti-dumping measures are by far the most frequently used instruments for protectionism. Alternatively, protectionist measures in the European Union have taken the form of (export) subsidies. These subsidies are mostly in the 'traditional' sectors, such as agriculture, fishing, coal and railways, but also in more high-tech sectors, such as airbus industries. On average, it seems that the European integration process diminished protectionism in the world. This, however, does not apply to the initially most liberal members; for example, the Union probably constrained Germany and The Netherlands in further liberalization (Winters, 1993).

The welfare effects of trade liberalization in the European Union were mainly measured by estimating (net) producer and consumer surpluses, that is (variants) of the surfaces of the so-called Harberger triangles. ${ }^{7}$ The measurements depend of course on the particular trade policies, but in a static competitive equilibrium framework there is equivalence between a tariff, an import quotum and an export tax. Furthermore, as Balassa (1976) observed, trade creation dominated trade diversion in the case of the European Union, which, within this framework, means that the Harberger triangles should be an acceptable approximation.

Summarizing the studies on the welfare effects of the formation of the European Union Balassa (1975) found that this formation contributed to some $0.5 \%$ of GDP. Possible improvements of productivity gains, caused by larger markets due to the formation of the European Union, are acknowledged, but no attempts to estimate this were made. ${ }^{8}$ More recent estimates suggest that the effects of further removal of protectionist measures are only 0.2 to $0.3 \%$ of the GNP of the European Union (Emerson et al., 1992). ${ }^{9}$ These studies therefore sug-

7 The theory behind these triangles is basic textbook material. Any textbook on trade theory will do. For a more advanced treatment see Vousden (1990) or Brakman and Jepma (1995).

8 Note that the relationship between size of the market and productivity also points to Verdoorn's Law. Indeed, the existence of economies of scale is often mentioned as an explanation of Verdoorn's Law. However, the generality of this law is not undisputed (see Fase and Winder, 1995).

9 Emerson et al. also pay attention to the measurement of dynamic effects, which are notoriously difficult to estimate. It is suggested (pp. 78-79) that the 'medium-run growth bonus' could range between $24 \%$ and $136 \%$ of the initial small static gains, leading approximately to an additional $0.3 \%$ of GNP gain (and a total gain of $0.5-0.6 \%$ of GNP). 
gest that the welfare effects of trade liberalization are quite small. The welfare effects may even be overstated because it is often assumed that the protectionist measures are completely abolished. Furthermore, one has to estimate import demand elasticities. Vousden (1990, p. 50) illustrates the sensitivity of the measurements of the welfare effects with respect to the values of the (compensated) price elasticities of demand for imports. In the calibrations these elasticities are often assumed to be relatively high, thus possibly overstating the welfare effects of a complete liberalization. Still, even with high demand elasticity estimates the welfare effects are small. For the United States, for example, the welfare effects of trade liberalization range between $0.01 \%$ and $0.1 \%$ of GDP. In Japan, one of the countries most criticized for protecting its local market, protectionism is confined mostly to agriculture and a small number of manufacturing industries, some of which are highly protected. The net cost for the Japanese society as a whole in 1989 ranges from $0.27 \%$ to $0.58 \%$ of GNP (Sazanami et al., 1995). For other countries the estimates are similarly small.

Various reasons have been brought forward to explain the seemingly small estimated welfare gains following trade liberalization. To a large extent the objections do not question the static nature of the estimates, but instead question the implicit assumptions within a basically accepted methodology of measuring the Harberger triangles. Problems addressed are, for example, inter-sector labour mobility, the type of import-demand function used (often an 'Armington' type demand function), aggregation problems, possible substitution effects between different types of importables, possible quality upgrading effects etc. Nevertheless, the welfare effects on the basis of this refined type of research remain small. The conclusion of the standard analysis within the neo-classical methodology is therefore that (Vousden, 1990, p. 51): '...the conventional static welfare costs of tariffs... are quite insignificant in relative terms.'

A more fundamental criticism questions the underlying model on which the traditional welfare estimates are based. Basically, this underlying model is characterized by trade in homogeneous goods and perfect competition. The models incorporating these basic features are the neo-classical trade models, the most famous of which is the Heckscher-Ohlin (H-O) model. How much of the world trading pattern can be explained using the perfect competition factor endowment theory? The answer to this question was given by Leamer (1984) and Bowen et al. (1987), among others. ${ }^{10}$

Tests of the H-O model relate relative factor endowments to net trade in these factors. Countries which have a particular production factor in abundance are expected to be net exporters of that factor (as embodied in international trade of goods and services). Bowen et al. (1987) perform two tests: first, a sign test for the relation of relative factor abundance and net factor exports; second a rank test, where the ranking of relative factor abundance should conform to the rank-

10 The literature on empirical tests of the H-O model is surveyed in Leamer $(1994,1995)$. 
ing of net factor exports. They find about $35 \%$ violations of the expected signs implied by the $\mathrm{H}-\mathrm{O}$ model and about $50 \%$ violations of the rank test and conclude that the H-O model in general performs poorly (see also Leamer, 1994). Other factors must be important in determining the unexplained part of world trade patterns. The next section identifies the missing link in explanatory power of the H-O model, indicating that world trade must to a large extent be explained by other models than the $\mathrm{H}-\mathrm{O}$ model. This turns out to be of crucial importance in explaining the low estimates of the welfare costs of protection in the traditional analysis.

\subsection{Protection}

The small estimated costs of protection have contributed to a continued supply of protection, as indicated in Tables 2 and 3 below which show that tariff and nontariff barriers remain high even after the Uruguay Round. After all, if a variety of interest groups demand protectionist measures, both on economic and non-economic grounds, it is tempting for politicians to give in to these demands if the estimated costs are small. The European Common Agricultural Policy can serve as an example. Regional and national politicians and interest groups demand specific measures to protect and preserve their agricultural traditions and interests. This holds for almost all European countries and agricultural industries and results in high across-the-board protection. The detrimental effects of this outcome are further discussed in the following section.

The success of the Uruguay Round can best be seen by comparing the second column with the third column in Table 2. For the industrial countries it is shown that, taking the applied rates as the base values, the import-weighted average tariffs on industrial imports will decline from 5.0 percent to 3.6 percent. For the European Union the decline is larger, from 5.7 percent to 3.6 percent. In a qualitative sense the same conclusion holds for the Non-tariff Barriers (NTBs); Table 3 reveals that the most important forms of non-tariff protection have declined.

A more detailed analysis of the individual items reveals that the tariff reductions differ considerably across products. The most dramatic tariff reductions have been made in sectors where the rates were low already, such as paper, pulp, furniture, metals, and nonelectric machinery. More limited cuts have been made in 'sensitive' sectors where the adjustment costs for the domestic industries and employees are considered high, such as textiles and clothing, transport equipment, steel, autos, aircraft, electronics, leather, rubber, and footwear. It seems hard for governments to restrain protectionist pressures, especially in the form of Voluntary Export Restraints (VERs) and anti-dumping measures. Nevertheless, the IMF 
TABLE 2 - PRE AND POST-URUGUAY ROUND TARIFFS ON INDUSTRIAL PRODUCTS ${ }^{11}$

\begin{tabular}{lccc}
\hline & $\begin{array}{l}\text { Import-Weighted } \\
\text { Average Bound } \\
\text { Rates } \\
\text { Pre-Uruguay Round }\end{array}$ & $\begin{array}{l}\text { Import-Weighted } \\
\text { Average Applied } \\
\text { Rates } \\
\text { Pre-Uruguay Round }\end{array}$ & $\begin{array}{l}\text { Import-Weighted } \\
\text { Average Bound } \\
\text { Rates } \\
\text { Post-Uruguay Round }\end{array}$ \\
\hline Industrial Countries & 6.0 & 5.0 & 3.6 \\
$\quad$ European Union & 5.7 & 5.7 & 3.6 \\
Japan & 3.9 & 1.9 & 1.7 \\
United States & 5.4 & 5.4 & 3.5 \\
Developing Countries & & & 30.9 \\
Argentina & 38.2 & 20.0 & 27.0 \\
Brazil & 40.7 & 15.0 & 8.3 \\
Korean Rep. & 18.0 & 7.9 & 9.1 \\
Malaysia & 10.0 & 9.1 & 28.1 \\
Thailand & 35.8 & 35.8 & \\
Transition Economies & & & 3.8 \\
Czech Rep. & 4.9 & 5.7 & 6.9 \\
Hungary & 9.6 & 11.0 & 3.9 \\
Poland & 16.0 & 11.6 & \\
Romania & 11.8 & 11.8 & \\
\hline
\end{tabular}

Souce: IMF, 1994, Volume I, p. 14 and Volume II, p. 6.

TABLE 3 - TRADE COVERAGE RATIOS OF CORE NON-TARIFF BARRIERS (NTBS) FOR THER EUROPEAN UNION, JAPAN, AND THE UNITED STATES; (IN PERCENT OF IMPORTS COVERED)

\begin{tabular}{lrr}
\hline & 1988 & 1993 \\
\hline Core NTBs & 14.6 & 14.0 \\
Quant. restrictions & 12.1 & 9.8 \\
Export restraints & 8.0 & 6.6 \\
Anti-dumping & 2.4 & 3.7 \\
Other price measures & 1.6 & 1.6 \\
\hline
\end{tabular}

Source: IMF, 1994, Volume I, p. 8.

11 Bound rates are the official tariff rates, which are the result of (previous) GATT negotiations and serve as a maximum tariff rate. Applied rates are the actual tariff rates, which are usually lower than the bound rates. 
(1994) concludes that protectionist pressures and trade frictions remain present and are escalating in some areas. ${ }^{12}$

\section{THE CHANGING STRUCTURE OF THE WORLD ECONOMY}

Of the many changes that the world economic system has witnessed over the past few decades we highlight two observations that are significant for this essay, namely (i) the importance of intra-industry trade, and (ii) the importance of the services sector. These two facts highlight the shortcomings of the neo-classical model. Moreover, they point to a conclusion, namely the increasing importance of imperfect competition in international trade. These findings are in correspondence with the presupposition of question 1 discussed in the introduction.

\subsection{The High-Level of Intra-industry Trade}

Most of world trade, some 57 percent in 1990, is trade between developed nations. Most of that trade, in turn, is intra-industry trade, or the simultaneous importing and exporting of similar products. Grubel and Lloyd (1975) demonstrated the high and rising level of intra-industry trade before there was a theoretical explanation. Why is France simultaneously exporting wine to and importing wine from Italy? Grubel and Lloyd's empirical finding greatly stimulated further empirical and theoretical research in international trade. The most convincing theoretical explanations of the phenomenon of intra-industry trade rely on scale economies, product differentiation and imperfect competition, thus forming a fundamental break with standard neo-classical trade theory which is based on constant returns to scale, homogeneous goods and perfect competition. ${ }^{13}$ Table 4 illustrates the high level of intra-industry trade, both in manufactured inputs, such as machinery, electronics and chemicals, and in manufactured final goods, such

12 Within the methodology of this section, the IMF estimates the tariff and non-tariff reductions of the Uruguay Round to lead to an increase in world income after a full implementation at somewhere between $\$ 212$ billion and $\$ 274$ billion (IMF, Volume II, p. 1 ), or approximately $1 \%$ of world income. 13 Some important contributions are: Krugman (1979, 1980), Ethier (1982), and Helpman and Krugman (1985). The static theories of intra-industry trade and inter-industry trade were elegantly combined with quasi-homogeneous demand by Markusen (1986) to explain the world level, structure and direction of trade. Grossman and Helpman (1991) investigate imperfect competition and intemational trade in a dynamic framework where returns to scale arise from the research and development costs required to invent a new variety or improve the quality of an existing variety. Krugman (1991) gives due attention to the location aspect identified by Balassa (1986) by incorporating transport costs in a model with both perfect and imperfect competition. This gives rise to positive feedbacks for locations, because industrial activity implies higher demand for differentiated goods and thus attracts more industrial activity, etc. Markusen et al. (1995, p. 204) also point to industrial classification as a determinant of intra-industry trade. Some trade is misleadingly measured as intra-industry trade because it is based on e.g. seasonal growing variations, or the simultaneous import and export for mid-product processing. 
TABLE 4 - INTRA-INDUSTRY TRADE INDEX, 1990

\begin{tabular}{lllrrrr}
\hline Commodity & Canada & Germany & Japan & S. Korea & U.K. & U.S. \\
\hline Fuels & 73.1 & 31.8 & 4.7 & 11.9 & 99.9 & 30.7 \\
Chemicals & 92.8 & 75.8 & 99.0 & 50.6 & 89.9 & 75.0 \\
Special Machinery & 62.5 & 45.6 & 35.5 & 26.9 & 89.7 & 91.8 \\
Computers & 46.3 & 74.7 & 39.0 & 68.4 & 95.3 & 99.8 \\
Automobiles & 79.7 & 58.7 & 26.0 & 10.1 & 62.3 & 37.5 \\
Clothing & 24.1 & 52.1 & 0.2 & 0.2 & 60.7 & 17.3 \\
Precision Instruments & 48.9 & 71.6 & 70.4 & 37.6 & 91.6 & 67.7 \\
\hline
\end{tabular}

Source: Markusen et al. (1995); the numbers indicate the share of intra-industry trade in total trade, measured by the Grubel-Lloyd index (100 if all trade is intra-industry trade; zero if all trade is inter-industry trade).

as automobiles. Intra-industry trade is particularly important in Europe, see e.g. Germany and the United Kingdom.

Empirical research on the testing of intra-industry trade theories is only just beginning and suffers from a number of specific difficulties: it is hard to find variables that closely measure the hypothetical variables suggested by theory (product differentiation, economies of scale, market identification, type of interindustry cooperation, etc.), each of which has different implications for the empirical relations (see also Fase, 1985). This means that the null hypothesis and alternative hypotheses are hard to formulate (think, for example, of the differences between non-cooperative oligopoly or cooperative oligopoly). These difficulties imply that simple indices of intra-industry trade are often related to variables which loosely measure some of the relations suggested by theory (Leamer, 1994, p. 86). The theoretical literature suggests, for instance, that the following variables can explain intra-industry trade: $(i)$ similarity in the level of per capita GNP, (ii) geographic-proximity, (iii) smaller trade restrictions, (iv) mutual borders, and $(v)$ economically integrated areas. The empirical study performed by Balassa (1986) confirms these relationships. These findings imply that the implementation of the latest GATT talks (the start of the WTO talks), and a continued economic integration of Europe, will further increase the level of intra-industry trade.

\subsection{The Increasing Importance of Services}

The arguments above, which indicate that the neo-classical trade model does not perform well in describing the present structure of international trade flows, is further strengthened by the fact that a substantial share of European trade is services trade. Services play an increasingly important role in today's world economy, as observed, for example, by the growing share in employment, pro- 
duction, exports, and foreign direct investment, see e.g. OECD (1993), UNCTAD and World Bank (1994) and Van Marrewijk, Stibora and De Vaal (1996). This growing importance of services in domestic economies and international trade, acknowledged by the political forum as testified by the inclusion of services in the Uruguay Round negotiations, is largely due to an increase in the production of producer services, see Grubel and Walker (1989), and OECD (1992). ${ }^{14}$ It has been estimated that the total value of across-the-border service trade is $\$ 900$ billion and that the value of services supplied by foreign subsidiaries of multinational firms is about $\$ 3000$ billion (Ministerie van Economische Zaken, 1994, p. 92). Firms increasingly delegate costly, knowledge-intensive intermediate-stage processing activities in their production process to specialized outside producers in order to gain cost advantages. Both the existence of considerable scale economies and the need to specialize services to the requirements of the buyer (provide many different varieties) necessitate the modeling of services provision in a framework of imperfect competition.

\subsection{Imperfect Competition ${ }^{15}$}

The high level of intra-industry and services trade indicates that world trade in general and European Union trade in particular is characterized by imperfect competition based on product differentiation and economies of scale (subsection 3.1). Similarly, the importance of services in general, and in the share of exports in particular, also indicates an increased importance of product variety and economies of scale in models of imperfect competition (subsection 3.2). Finally, the impact of international trade policy is increasing due to rising international interdependence (section 2). Thus, the stylized facts of the world economy discussed so far lead to the following conclusion: the importance of imperfect competition in international trade is considerable. Corroborating evidence is found in the increasing importance of multinational enterprises. There were some 37,000 multinational corporations with 170,000 foreign subsidiaries in 1991. Despite the rapid rise in world exports the sales of these foreign subsidiaries have increased more than three times as fast in the period 1960-1991, and are now actually larger than the total value of world exports. In that same period the share of foreign direct investment in total investments more than doubled. The next section of this paper investigates the consequences of the increased importance of imperfect competition for practical international trade policy prescriptions.

14 The negotiations, which were very difficult, resulted in the GATS (General Agreement on Trade in Services) on December 15, 1993. Negotiations on services trade still continue, now within the World Trade Organization.

15 The data in this subsection are from the UNCTAD (1993) World Investment Report. 


\section{THE UNDERESTIMATED COSTS OF PROTECTION}

This section answers the first two questions posed in the introduction: what should European trade policy be in a world increasingly dominated by imperfect competition and how should Europe respond to protectionist measures imposed by its trading partners? The answer based on traditional economic analysis, with perfect competition and low estimated costs of protection, is that protection could in principle be used as a policy tool. For example, the use of protection to cater to the needs of specific interest groups (e.g. airbus industries), or the imposition of tariffs to extort concessions from trading partners is, within this framework, thought to be relatively harmless from a welfare perspective. ${ }^{16}$ We question the crucial empirical findings of the low estimated costs of protection because these findings are based on the, at least partially irrelevant, premise of perfect competition (see section 3). Accurately estimating the costs of protection and trade barriers, or the gains from economic integration, is extremely difficult. In (dynamic) models of imperfect competition in which new goods and services are invented over time and characterized by economies of scale, the costs of protection can potentially be much higher than the traditional measurements of the welfare costs of protection suggest. The purpose of this section is to substantiate this claim.

\subsection{Static Costs of Protection under Imperfect Competition}

Empirical studies on the cost of protection under imperfect competition, excellently surveyed in Richardson (1988), indicate that the costs of protection are generally higher under imperfect competition. Indeed, Richardson (1988) in his survey concludes (p. 2): 'the gains could be two to three times the size of those estimated under traditional assumptions.' For example, typical estimates of the gains from economic integration between Canada and the United States in a static, perfect competition framework, taking trade creation and trade diversion into account, estimate the gain to Canada in the order of magnitude of 1 percent of GNP. Instead, Harris (1991), using a static computable general equilibrium model that allows for economies of scale arrives at a 3 times larger gain for Canada (3.2 percent of GNP), mainly resulting from a better use of such scale economies. Larger gains, one might say, but still not quite spectacular. Feenstra (1995) argues that the application of static techniques to imperfect markets suggests that the welfare effects of trade liberalization are somewhat higher than traditional perfect competition measurements, because foreign firms will in general only partly pass the tariff rate through to consumers resulting in an (extra) terms of trade gain for the tariff-imposing country. In general the empirical studies investigating

16 It should be noted that tariffs are only a second-best instrument if politicians want to transfer income to their favoured constituency. A tariff creates an overall distortion in the economy. A lumpsum transfer or a suitable combination of consumer or producer taxes and subsidies is clearly better than a tariff from a welfare point of view (Dixit and Norman, 1980). 
the welfare effects of trade from better use of scale economies through an expansion of plant output find mixed or only mildly positive results, see e.g. Tybout (1993). This is not surprising if we keep in mind the most simple intra-industry trade model based on variety with constant elasticity of substitution which does not predict any change in operating size of plants. Instead, the gains from trade in such an economy come exclusively from quality improvements, a love-of-variety effect (for consumer goods) or external economies of scale (for intermediates), all of which are notoriously difficult to handle empirically.

An indication of the costs of protection under imperfect competition for Europe can be given by using the gravity model, which states that economic proximity and trade flows are positively related. The gravity model initially had a mixed reputation: successful empirically, but relying on questionable assumptions to derive the model theoretically. ${ }^{17}$ Recently, however, the gravity model has regained some acceptance because its basic equation can be derived from models with increasing returns to scale, product differentiation and imperfect markets (see Appendix A). ${ }^{18}$

Our empirically estimated log-linear formulation of the gravity model is ${ }^{19}$ :

$$
\begin{aligned}
T_{i j}=- & 28.04+0.6296 * Y_{i}+0.8571 * Y_{j}+0.0599 * N_{i}+0.1514 * N_{j}- \\
& (57.8) \quad(42.240) \quad(55.925) \\
- & 1.0294 * D_{i j}-1.3367 *\left[P_{i}+P_{j}\right] \\
& (-33.500) \quad(-11.598)
\end{aligned}
$$

where $t$-statistics are given in parentheses; $T_{i j}$ is trade flow from country $i$ to country $j ; Y_{i}\left(Y_{j}\right)$ is Gross National Product of country $i$ (and $j$, respectively); $D_{i j}$ is the economic distance between countries $i$ and $j, N_{i}\left(N_{j}\right)$ is the population size of country $i$ (and $j$, respectively); this is a proxy for scale economies; and $P_{i}\left(P_{j}\right)$ is an indicator for protectionist measures of country $i$ (and $j$, respectively). Bilateral trade is large if both countries are (economically) large (in GNP and population), the distance is small and trade barriers are low.

The influence of protection on trade flows, using the gravity model, can be calculated as follows. First, the gravity model is estimated including actual protectionist measures, see equation (1). Second, on the basis of this estimation the hypothetical trade flows can be calculated by assuming that the barriers of trade are absent. The trade flows predicted by the model without barriers to trade rela-

17 The traditional standard formulation suggests that the model can only be used under special circumstances, for example if bilateral trade flows are in equilibrium (see Brakman, 1991).

18 Furthermore, Helpman (1987) and Hummels and Levinsohn (1993) show that current account imbalances hardly bias the estimations.

19 Based on 5984 actual data entries, starting with 1992 bilateral trade data for 199 countries. Adjusted $R$-square: $0.61, F$-statistic: 1555.34 , see Appendix B for further details. 
TABLE 5 - PREDICTED INCREASE IN TRADE FLOWS WITHOUT PROTECTION

\begin{tabular}{lcc}
\hline Country & Export to ROW & Import from ROW \\
\hline United Kingdom & 1.252 & 1.194 \\
Belgium/Luxembourg & 1.456 & 1.261 \\
Denmark & 1.175 & 1.163 \\
France & 1.224 & 1.189 \\
Germany & 1.236 & 1.208 \\
Italy & 1.209 & 1.225 \\
Netherlands & 1.240 & 1.216 \\
Greece & 1.206 & 1.260 \\
Ireland & 1.116 & 1.105 \\
Portugal & 1.191 & 1.280 \\
Spain & 1.280 & 1.268 \\
\hline & Export to EU & Import from EU \\
& 1.069 & 1.069 \\
\hline United Kingdom & 1.093 & 1.094 \\
Belgium/Luxembourg & 1.103 & 1.105 \\
Denmark & 1.072 & 1.072 \\
France & 1.094 & 1.095 \\
Germany & 1.073 & 1.073 \\
Italy & 1.101 & 1.100 \\
Netherlands & 1.099 & 1.100 \\
Greece & 1.063 & 1.058 \\
Ireland & 1.111 & 1.110 \\
Portugal & 1.100 & 1.099 \\
Spain & & \\
\hline
\end{tabular}

The entries in the table give the trade flows predicted by the model without barriers to trade relative to the actual trade flows. ROW indicates the Rest of the World, EU indicates European Union.

Source: own calculations, see Appendix B.

tive to the actual trade flows give an indication of the influence of protectionist measures. ${ }^{20}$ Table 5 presents these calculations for some European countries, both the trade within the European Union and outside the European Union. Thus, following this procedure, the worldwide abolishment of tariffs leads to an estimated increase in Dutch exports (imports) to (from) the countries of the European Union of $10.1 \%(10.0 \%)$ and to (from) the Rest of The World of $24.0 \%$ (21.6\%). These estimates and their size are rather typical for most European countries: within

20 That is, the predicted export from country $i$ to country $j$ without trade barriers is equal to the actual export from country $i$ to country $j$ divided by $\exp \left[-13367\left(P_{i}+P_{j}\right)\right]$. This methodology has the advantage that it accommodates actual trade idiosyncrasies not predicted by the model. 
Europe the gains from diminishing protection are smaller than with respect to the Rest of The World, as might be expected for countries within a preferential trade agreement.

The calculations in Table 5 give an indication of the static trade-related costs of protection. Although substantial, we argue below that these values still underestimate the dynamic costs of protection. Indeed, a second, and much more important, shortcoming of the empirical studies on the cost of protection is the absence of adequate dynamics. As Richardson (1988, p. 14) in his survey puts it: 'All of the empirical research...is in essence an empirical analog to comparative statics' which, moreover, is 'more art than science.' This is indicated most clearly in the study of Daniella Markheim (1994) evaluating the accuracy of 10 ex ante studies on the projected trade effects of 7 different preferential trade agreements, 5 of which pertain to Europe. She finds that only 5 years after the investigated preferential trade agreements take effect no less than between 49.7 per cent and 99.8 per cent of the actual increase in trade flows is not predicted by the ex ante studies. ${ }^{21}$ The $e x$ ante studies therefore uniformly underestimate the impact of trade policy changes on trade flows, regardless of the type of trade policy change or the level of development of the implementing countries. Apparently, trade policy changes invoke countries to shift larger amounts of resources towards the production and supply of exports which is not fully accounted for in the calculation of ex ante estimates. This demonstrates that dynamics, not statics, should be the driving motivation behind economic integration and international cooperation. We will argue our case below through historical anecdotes, two numerical examples, and a theoretical discussion of growth effects.

\subsection{Dynamic Costs of Protection under Imperfect Competition}

\subsubsection{History and protection}

To remove the static nature of empirical studies on the cost of protection one would like to investigate the consequences of trade policy changes over a somewhat longer period. After the feudal period Japan moved from virtual autarky in 1858 to nearly free trade in the 1870 s. The trade level jumped from practically zero to 7 percent of GNP, the terms of trade improved by 340 percent, and national income rose by about 65 percent in 15 years. This development in Japan strongly suggests that there is a relationship between the growth of national income and protectionism, see Huber (1971) for further details.

Other indications of the dynamic benefits of international free trade over a longer period are provided by different developmental strategies. India, for example, has had an inward-looking strategy of development, based on import substitution, for a long time and, as is evidenced from Table 1, was not particularly

21 The best performance ( $49.7 \%$ of the increase is not predicted) is a study by Miller and Spencer (1977) estimating a $50 \%$ increase in exports from the UK to the EC. 
successful. Other countries, e.g. in South America, could be used to illustrate the same point. The more successful South East Asian countries adopted in general rather open and outward-oriented development strategies based on export promotion. This does not mean that a country such as South Korea never adopted an import substitution policy, because it did. It does mean that whenever such a policy was adopted it was based on an infant industry argument and the ultimate goal was to export such goods over time. ${ }^{22}$ Finally, a fair case can be built on the hypothesis that the inward-looking nature of the East European countries, which shielded their economies from the fierce competition and technological and product innovations of the world economy, can at least partially explain the collapse of the system some 7 years ago. ${ }^{23}$

The examples above clearly suggest a relationship between openness and economic growth. ${ }^{24}$ Studies explicitly dealing with this issue, mostly employing cross-country comparisons, find that growth often is enhanced by openness, see Sachs and Warner (1995).

\subsubsection{New products and protection}

Romer (1994) gives an excellent description of the welfare costs of protection if new and useful goods and services are invented over time. The traditional measurements of the welfare effects of protection all calculate the possible costs within an existing set of products. It is crucial to note that the Harberger triangles, which are the basic welfare measures of the traditional analysis, can only be measured if products are actually present in an economy. This could seriously understate the true cost of protection if protection results in fewer products of lower quality than would otherwise exist: if products are not developed due to protectionism the associated consumer surplus or income will never be realized. Due to the very nature of this argument empirical results do not exist. Nonetheless, a simple example can illustrate the potentially impressive size of these costs (see Romer, section 7, for details).

The model is given a rudimentary time dimension, which suffices for our purposes, by distinguishing between expected and unexpected policy measures. Take

22 The South Korean shipbuilding and automobile industries can serve as examples here.

23 In a survey of the literature on the relation between exports and growth Greenaway and Sapsford (1994) find that the methodology of research partly determines the answer: in cross-section studies the relation between exports and growth appears positive, while in time-series analysis the same degree of agreement on the relationship is absent.

24 Well-known studies on the link between openness and growth are co-ordinated by Bhagwati and Krueger in the NBER multi-country project on 'trade regimes and economic development.' The overall conclusion of this project supports the notion that growth is stimulated by openness. The literature on this subject and the methodological problems concerned are surveyed by Leamer (1994). 
a country whose output level $Y$ is a function of labour $L$ and a large number of different types of capital goods $x$ indexed by $i$ :

$$
Y=L^{0.5}\left\{\sum_{i=1}^{n}\left(x_{i}\right)^{0.5}\right\}
$$

The capital goods are all imperfect substitutes for one another and can be thought of in physical terms, such as blast furnaces, buildings, computers, and fork lift trucks, or in terms of intermediate specialized human capital services, such as accounting, engineering, and banking. Given the number of varieties $n$ there are constant returns to scale in the economy: a doubling of all inputs leads to a doubling of output. However, an increase in the number of varieties, i.e. the invention of a new (physical or human) capital good, necessitates a reallocation of capital inputs and also causes a rise in production. The increase in the number of varieties affects the marginal productivity of the other inputs. This is a positive externality which is not taken explicitly into consideration by the inventors of new varieties.

Suppose, for simplicity, that the inventors of a capital good, or the entrepreneurs owning the rights of production of a particular capital good, all live abroad. It is well-known that for the production function given in equation (2) the elasticity of demand for a particular variety of a capital good is constant (and equal to 2 in this case). This implies a simple optimal pricing rule for the entrepreneurs to maximize profits, namely a constant mark-up (also of 2) over marginal costs. The latter are assumed to be constant. Gross profits from selling a good in this market then turn out to be half of total sales. The basic decision facing the entrepreneurs is whether or not to introduce the capital good on the market. Suppose that the costs of introduction are (linearly) rising with the index $i$. These costs represent, for example, the costs of setting up a services and parts supply network, or setting up a local branch consulting office. The entrepreneur will only introduce the capital good on the market if the gross profit from sales is higher than the cost of introducing the good on the market. Without any government intervention this decision endogenously determines the number of capital good varieties introduced on the market and a benchmark production level $Y^{*}$.

Consider the effects of government intervention in the form of imposing an ad valorem tax or tariff $\tau$ on all purchases of foreign imported goods under two different experiments. ${ }^{25}$ The first is to calculate the loss in output, relative to the benchmark $Y^{*}$, resulting from an unexpected government action, that is after the entrepreneurs decided on the introduction of their capital good on the market. Because entry costs are sunk costs this unanticipated government policy does not affect the number of varieties available in the economy. Such a policy does af-

25 Since all intermediate goods are imported an import tariff and a tax on intermediate inputs have the same effect. 
fect, however, the mark-up decision of the entrepreneur because of the wedge between the price paid by the final goods producer and received by the intermediate goods supplier (actually, the mark-up changes at the rate $1 /(1-\tau)$ ). These higher prices lead to lower imports of capital goods and result in lower output. Romer (1994) calculates the unexpected cost of protection (measured as the reduction of output relative to the benchmark $\left.Y^{*}\right)$ as: ${ }^{26}$

$$
\text { unexpected cost of protection }=\tau^{2} \quad(=\text { short-run costs of protection })(3)
$$

We identify the short-run costs of protection with the unexpected costs because in the short run there is no significant change in the number of physical or human capital goods available. The second tax experiment is to calculate the loss in output, relative to the benchmark $Y^{*}$, resulting from an expected government action, that is before the entrepreneurs decide on the introduction of their capital good on the market. Because the tax rate lowers after tax profits since the higher mark-up reduces the quantity sold of a particular capital good this anticipated government action reduces the number of varieties introduced on the market. This loss in variety is an important additional cost of protection. Romer (1994) calculates the expected cost of protection (also measured as the reduction of output relative to the benchmark $Y^{*}$ ) as:

$$
\begin{aligned}
\text { expected cost of protection }= & 2 \tau-2 \tau^{3}+\tau^{4} \\
& (=\text { long-run costs of protection })
\end{aligned}
$$

Figure 1 illustrates the short-run and long-run costs of protection in this simple framework. The long-run costs of protection are significantly higher than the short-run costs of protection. For example, if the tax rate is $20 \%$, the reduction in output is $4 \%$ if this policy is unexpected (short run), and an astounding $38.6 \%$ if this policy is expected (long run). Thus, the short-run costs of protection are significant, but bearable. ${ }^{27}$ Over time, however, new and useful goods and services are invented abroad which are not introduced on the domestic market because the (by now anticipated) degree of protection ensures that the costs of introduction cannot be covered by the gross operating profits. Thus, the long-run costs of pro-

26 The intuition underlying equations (3) and (4) can be understood as follows. Income in Romer's model equals the share of labour in gross domestic product plus tariff revenue. Gross domestic product is a function of labour, the number of varieties and the volume per variety. Furthermore, the number of varieties, $N$, is a function of the tariff rate, $\tau$. These expressions are substituted in an equation which measures the efficiency loss for the economy as a fraction of national income relative to the benchmark income $\left[Y^{*}(0)-Y(\tau)\right] / Y *(0)$. Equation (3) follows if $\tau$ is substituted in this expression for a given number of varieties and (4) follows if $\tau$ is also allowed to affect the number of varieties.

27 The order of magnitude roughly corresponds to empirical estimates. 


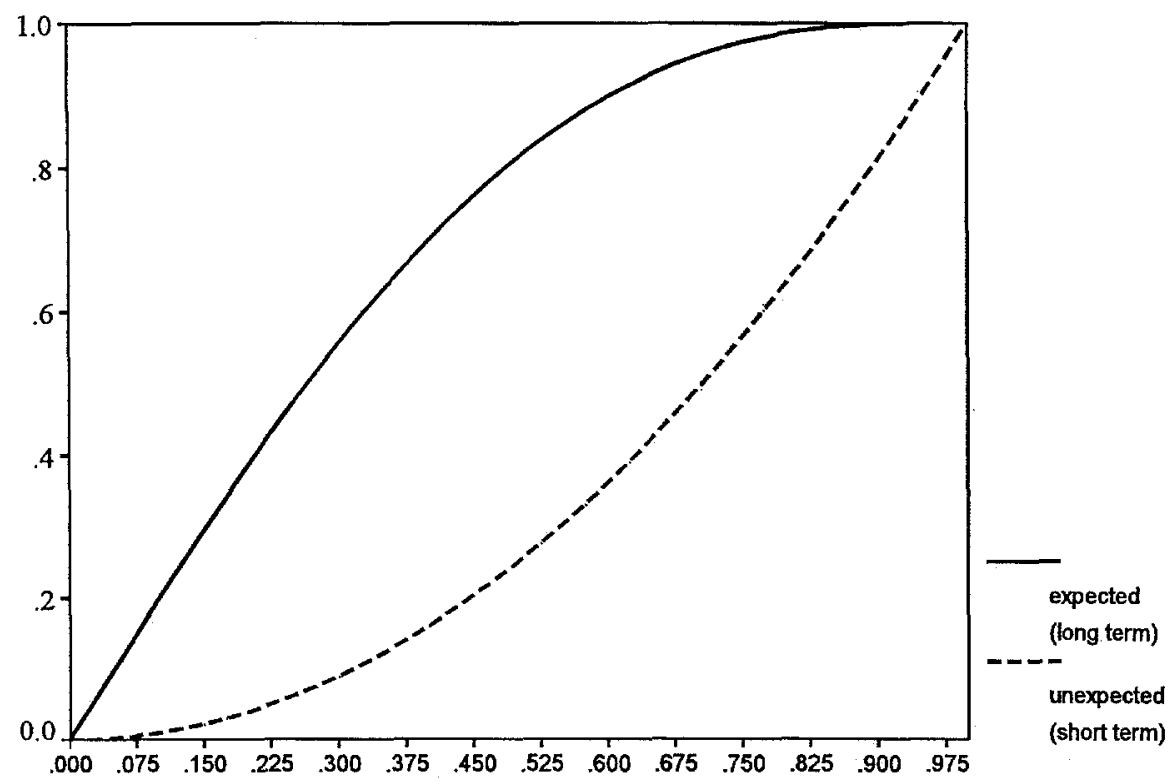

tariff

Figure 1 - The costs of protection

tection are very high, much higher than the analysis in section 2 suggest, and therefore in the long run ultimately unbearable for most countries.

\subsubsection{Quality and protection}

The high costs of protection are further amplified if we take into consideration the fact that most production processes are subdivided into several tasks. For example, in the production of cut flowers one task may be the picking of the flower, a second task the transportation of cut flowers to a central production area, where a third task is the sorting of the flowers with respect to colour, size and quality, a fourth task may be temporary watering of cut and sorted flowers, a fifth task the packaging, a sixth task transportation to the auction, and so on, and so forth. At each step there is a certain probability of mishandling of the product, depending on the quality of the people performing the task, which renders the product useless (or diminishes its value). Kremer (1993) analyzes a simplified version of such 'O-ring' production functions. ${ }^{28}$ Let $q$ be the probability that a certain production task is performed satisfactorily and let $n$ be the number of production tasks. Kremer shows that it is optimal for a producer to hire people of the same

28 The name 'O-ring' production function is derived from the space shuttle Challenger, which consisted of thousands of different components before its fatal journey. Of those thousands of components the 'O-ring' malfunctioned, rendering the end product worthless in a violent explosion. 
skill level (identical $q$ ) and that the wage paid is proportional to $q^{n}{ }^{29}$ To the extent that trade restrictions prevent bypassing of domestic bottleneck sectors, such restrictions can diminish domestic productivity. This reasoning assumes that protection induces domestic producers to perform tasks in their own factory which could be more efficiently performed by (specialized) foreign firms.

Suppose, for example, that low domestic capacity or quality in one of the production steps is accommodated by an $80 \%$ reliability $(q=0.80)$ in a simple production process. If the alleviation of trade restrictions now mildly increases reliability by $10 \%$ from $q=0.80$ to $q=0.88$, this leads to a dramatic 10 -fold increase in total productivity and the wage rate if there are at least 24 production steps $(n \geq 24)$. Even a meager $1 \%$ reliability improvement would raise wages and total productivity by more than $27 \%$ under such circumstances. Similar calculations for complicated production processes involving several hundreds or even thousands of production stages or components lead to productivity gains that numb the mind. ${ }^{30}$

\subsubsection{Dynamic theories and protection}

On the theoretical side, Rivera-Batiz and Romer (1991) analyze the effects of protection and economic integration on the growth rate of the economy by distinguishing a production sector and a research and development (R\&D) sector responsible for the increase in the (domestic or world) stock of knowledge. Let $F(Z)$ to the production function of the $R \& D$ sector, where $\mathbf{Z}$ is a vector of inputs. Economic integration of two identical countries within this framework can, in principle, either increase or decrease the growth rate of the economy. Three effects are important in this respect. First, to the extent that there are economies of scale in the R\&D sector, the integration effect will increase the rate of economic growth, i.e. $F(2 \mathbf{Z})<2 F(\mathbf{Z})$. Second, to the extent that the output of the R\&D sector is duplicated in the two countries in the absence of economic integration, a redundancy effect will also increase the growth rate of the economy because it will free resources for productive use. That is, in an integrated world no resources will be wasted to re-invent the wheel, the compact disc, or the highdefinition television. Given the distribution of human capital over the productive

29 Basically, this follows from optimizing revenue minus cost of employing labour and capital. The wage rate, $w$, is a function of quality or reliability, $q \in[0,1]$, which measures the average probability that a specific task is performed successfully. The production function in this optimization problem is $y=k^{\alpha} q^{n} n B$, where $k$ is capital, $B$ the output per worker and $n$ the number of tasks. From the firstorder condition we have $w^{\prime}(q)=q^{(n-1)} n B k^{\alpha}$; integrating this expression gives the result stated in the text (the integration constant is zero due to the fact that total revenue equals payment to capital and labour).

30 Even in the fairly simple cut flower example it is easy to identify more than 100 different tasks to be performed. Just think, for example, of the various substages of plant selection, nursing, planting, weed control, pest control, fertilizing, heating, etc. Not even mentioning the selling of the flowers at the auction and the route from the auction to the consumer. 
sector and the research and development sector this leads to higher growth. Third, to the extent that the process of economic integration changes the relative prices of capital goods, skilled and unskilled labour and the like, this entails a redistribution of those inputs between the production sector and the R\&D sector. This allocation effect increases the growth rate if resources are shifted into the R\&D sector, and reduces the growth rate otherwise. As Rivera-Batiz and Romer show the third effect can potentially dominate the first two effects.

There is some support for this model. Haaland and Norman (1992) show, in a general equilibrium world trade model, that the establishment of a unified single market within Europe will shift resources to the R\&D or skill-intensive engineering sectors, and stimulate economic growth.

We acknowledge that the preliminary theoretical work of Rivera-Batiz and Romer is important, but at the same time want to point out some of its limitations. First, the authors assume that the R\&D sector uses only human capital (and knowledge spillovers) for its production. Thus, no physical capital goods or unskilled labourers, no supercolliders, computers, buildings or janitors, are used to produce product or process innovations. ${ }^{31}$ Second, the world stock of knowledge enters in the R\&D sector after the process of economic integration and it is assumed, rather than analyzed, that the production processes in the R\&D sectors of Japan, Europe and the United States are integrated. Thus, knowledge generated in a laboratory in Japan flows freely, and instantaneously, to laboratories in Italy, Germany and The Netherlands. This contrasts strongly with the importance of proximity in knowledge spillovers stressed by many others, see e.g. Krugman (1991) with California's Silicon Valley (and Malaysia's budding Penang Island) as the standard example, and Head et al. (1995) for empirical evidence on a variety of industries. Third, it is again assumed rather than analyzed that economic integration will abolish the phenomenon of redundancy. The doubtfulness of this assumption is illustrated by the fact that even within the same country a number of firms are usually working on the same problem. In Japan, for example, a number of firms are working simultaneously on developing high-definition televisions. Even if economic integration were to reduce the world-wide number of firms working on the same problem, it is questionable whether this reduction in 'redundancy' is always beneficial as it might at the same time reduce competition. Indeed, one might argue that the increase from the domestic to the world number of firms working on the same problem is an important source of procompetitive gains from trade. Finally, some economists also question the basic ideas underlying the endogenous growth literature, see e.g. Solow (1994).

31 A companion paper (Rivera-Batiz and Romer, 1991b) uses the equally restrictive assumption that $\mathrm{R} \& \mathrm{D}$ technology is identical to that of goods and services production. 


\subsection{Conclusion}

The answer to the first two questions posed in the introduction must now be clear: in a dynamic world economy pervaded by imperfect competition it is important, more so than in a world characterized by perfect competition, that European trade policy is directed at free and open markets, no tariffs, quotas or other non-tariff barriers should be imposed because this is detrimental to European welfare and economic development. Furthermore, traditional (perfect competition) analysis of the welfare costs of protection possibly underestimates the actual costs of protection (in the presence of imperfect competition), which increases the temptation for policymakers to give in to demands for protectionist measures. In a first-best Pareto-optimal world, i.e. under perfect competition, all interventions (such as tariffs) have small second-order welfare effects; hence the low estimated costs of protection discussed in section 2 . In an imperfectly competitive world that is not first-best Pareto-optimal, interventions have large first-order welfare effects. The first-order welfare losses of protection were discussed in this section. As Romer (1994, p. 8) puts it: 'the assertion that an equilibrium is not first-best Paretooptimal does not validate any arbitrary intervention. It just raises the stakes. Trade restrictions are a little bit harmful in the usual model of perfect markets. They are very harmful in the second-best world. ${ }^{32}$

\section{CURRENT ISSUES}

The traditional economic analysis of trade policy based on perfect competition, with its shortcomings emphasized above, has one great advantage: in theory protection is almost always harmful. In contrast, the new trade theory, developed to explain the stylized facts of international trade allows for 'strategic' trade policies. Thus, a major disadvantage of the new trade theory is the ease with which it can be abused to validate demands for protectionist measures. The current fear of competition from 'low wage' countries further fuels this demand. Thus, lobbyists for special interest groups can attract a lot of sympathy for their case by simultaneously pointing at 'unfair' competition from low-wage countries and using semi-sophisticated theoretical arguments. The discussion in this section addresses these issues and simultaneously answers question 3 posed in the introduction.

\section{1 'Strategic' Trade Policies}

An argument for trade protection, known as 'strategic' trade policy, has attracted a lot of attention over the past decade. We outlined in section 3 that many new theories have been developed to incorporate a wide range of real world phenom-

32 Note that imperfect competition implies that we live in a 'second-best' world. 
ena, such as economies of scale, imperfect competition, variety, quality improvements, etc. The details of these models differ as widely as the phenomena they try to explain. However, in one respect they tend to be rather robust: government intervention has the potential to increase welfare. We give two examples. First the 'optimal' tariff rate is never zero, no matter how small the country or region in question (Helpman and Krugman, 1989, p. 139 and p. 143). Second, the optimal government policy is to subsidize the export sector if firms compete in quantities. ${ }^{33}$

Strategic trade policy has several drawbacks. All these models are examples of one-shot games. Take the 'optimal' tariff argument for protection as an example. This is the tariff rate which maximizes a country's welfare, taking the tariff rates of other countries as given, i.e. in the absence of retaliation. ${ }^{34}$ Furthermore, the specific welfare-maximizing policies depend crucially on the model specification. If producers compete on the basis of prices rather than quantities in the second example above, the optimal government policy is to tax rather than subsidize the export sector. ${ }^{35}$ Finally, the accurate implementation of strategic trade policy by the government requires a formidable knowledge of all sectors in the economy concerning the type of competition, the knowledge spillovers, etc. In short, more information than is usually available. Thus, the 'free trade' policy prescription does not follow from imperfect competition models as an inevitable conclusion but, in conjunction with the high potential costs of protection discussed in the previous section, as a useful rule of thumb.

\subsection{Competition from Low Wage Countries}

A different, and rather crude, argument has also attracted much attention recently. Both the United States and Europe are currently experiencing a relative decline of their national economies. As was the case with Britain at the end of the nineteenth century, the relative decline of an economic leader tends to increase the demand for protectionism. The cause of such fears is the increased economic importance of the 'emerging economies.' Protectionist measures are often motivated by stating that 'our markets are more open than yours.' These claims, e.g. illustrated by anecdotal evidence of Japan's closed market, may to some extent be

33 See, for example, Brander and Spencer (1985), Spencer and Brander (1983) and the survey of Brander (1995).

34 One can now investigate a game in which all countries are involved in a Nash game to set their 'optimal' tariff rate to arrive at a non-zero Nash equilibrium 'optimal' tariff rate for all countries. In the process all countries are adjusting their tariffs, violating the basic non-retaliation assumption. More importantly, the final equilibrium tariff rate is not optimal because all countries could do better by charging a zero tariff. It is the classic example of a prisoner's dilemma, discussed further in the next section.

35 Further complications arise with other strategic variables, first and second-mover problems, etc. 
correct, but as Table 2 shows Japan's tariff rates are among the lowest in the world.

The employment problems in Europe and the United States are often attributed to 'unfair' competition from low-wage countries (Krugman and Lawrence, 1993b). According to this argument less developed countries and countries from Eastern Europe with huge supplies of unskilled and low-paid workers are responsible for the high levels of unemployment in Europe and the United States. The wages in these countries are so low that the rich countries cannot compete anymore. In this context it has been pointed out repeatedly that labour conditions in third world countries are often appalling, just think of involuntary child labour. Tackling the source of the problem, by helping to improve labour conditions, facilitating better schooling and trying to convince other countries to pass and enforce child labour protection laws, is obviously superior to the advocated imposition of trade restrictions on the goods the poor countries are exporting. The latter not only hurts the developing nations, and thereby aggravates the problem, but also gives the impression that the proponents of such trade restrictions are more concerned about their constituents are (re-)election than the labour conditions in developing countries. These arguments are not only almost always (mis-) used in an ad hoc manner to demand more protectionist measures, they are also almost always wrong (see also subsection 6.1).

In a recent debate in Foreign Affairs (1994, March/April and July/August) two opposing views are distinguished. Both views take the premise that governments should act in the interest of their own constituents, and not of the world as a whole, as starting point. On the one hand, Krugman (1994) claims that the obsession with competitiveness is based on wrong conceptions and erroneous data. ${ }^{36}$ On the other hand, various authors claim that the United States and Europe on the one hand and the emerging economies on the other flight a competitiveness battle with each other (like Pepsi-Cola and Coca-Cola) which is unwinnable for Europe and the United States because of the low wages in, for instance, Asia. The latter claims are wrong. First, low wages are accompanied by low labour productivity. Furthermore, competitiveness is a complex variable which not only consists of labour costs but also on (the efficiency of) the financial sector, government policies, economic stability, monetary policies, etc. Taking a variety of these factors into account The Netherlands, for example, is number eight in a ranking of the most competitive nations despite relatively high wages (behind, among others, the United States, Japan and Germany; Van der Zwet, 1995). Thus comparing wages is not very informative for measuring competitiveness. It is important

36 Specifically, Krugman (1994) shows that the employment problems of the United States are caused by internal problems and are not caused by increased foreign competitiveness. The decrease in employment in the industrial sector and the diminishing share of this sector in GDP are largely due to the growth of (labour) productivity in the industrial sector. Grosso modo these conclusions also apply for The Netherlands (Van der Zwet, 1995). 
in this respect to point out that the major competitors of, for example, many Dutch producers are located in Germany, Belgium, France, etc., all of which are not low-wage countries. Second, the theories of international trade explain that everyone can still benefit from international trade, based on comparative advantage, economies of scale, variety, quality, etc. Third, the fact that productivity growth in Asia is higher than in the United States or Europe poses no particular threat to the latter countries because of the low starting value of productivity in the (initially) less developed country. For example, Pilat (1993) shows that a South Korean labourer was only 9 percent as productive as an American labourer in 1975 . Fourth, real wages are unaffected by productivity growth abroad, but only depend on productivity at home. This holds even if one country surpasses another. Finally, foreign competitive pressure and the threat of copying ideas (without payment) from leading industrial nations may be welfare increasing in a dynamic context because attempts to stay one step ahead of the copiers increases the rate of innovation in the developed world (Grossman and Helpman, 1991).

In response to the competitive pressures from low-wage countries in Asia and Eastern Europe the countries of the European Union have to adapt their production processes according to their comparative advantage, that is toward medium and high-technology sectors. Germany, for example, clearly benefits from its know-how in machine production in view of the increased investment demand from newly industrializing countries in Eastern Europe and Asia. Other countries, notably The Netherlands, benefit indirectly as suppliers of intermediates to the German machine industry, or simply from the rising demand from germany in general. Although comparative advantage may thus change from one good to another over time, giving rise to adaptation problems, trade based on comparative advantage, economies of scale, quality of variety remains beneficial to all. Concluding this section we do not want to play down the (temporary) adverse effects for some industries and workers involved, which can be very severe indeed, but our conviction is that there is no viable alternative to participation in the international trade game.

\subsection{Conclusion}

Europe should welcome low-cost competition from other parts of the world, such as Eastern Europe and South east Asia. This simply reflects shifting patterns of dynamic comparative advantage, the development of nations and the extent to which some goods are no longer in the 'high-technology' categories of production. Meeting the competitive challenge spurs innovation and increases productivity. The demand for protection under these circumstances is largely based on misconceptions and erroneous data. For example, low wages are accompanied by low productivity, while economic development opens new opportunities for a variety of sectors. Desperately trying to hold on to uncompetitive industries is about as useful as trying to stop the sun from rising in the morning. We saw before, in 
section 4 , that the costs of protection may be underestimated. The danger is that it might, in conjunction with the continuing demand for protection, ill founded or not, lead to a continuing (and excessive) supply of protection, as shown in Tables 2 and 3.

\section{TRADE POLICY UNDER IMPERFECT COMPETITION}

If free trade is better than managed trade, what is the best policy option for a government in a world where other governments protect their national markets? Two options come to the fore: $(i)$ participate in international negotiations which reduce protection between participating countries and (ii) retaliatory measures which coerce trading partners to become more liberal with respect to trade policies. In practice the first option leads to ever larger regional trading blocs. This option has the intuitive appeal that the process leads to more free trade and in principle should only stop when the whole world has joined a free trade zone. However, it also has its drawbacks as discussed below. The second option leads to power politics and the risk that trade policy becomes entrapped in ever escalating retaliatory measures. The consequences of this policy will also be discussed below.

\subsection{Regional Trade Arrangements}

The formation of regional trade arrangements has become increasingly popular. The extension of the European Union with new members and the formation of NAFTA are examples of increasing regionalization. ${ }^{37}$ According to the (former) GATT, regionalism should be a step in the process towards freer trade (article XXIV of the GATT). At first sight the formation of ever larger regional free trade blocs is a sound policy towards the eventual goal of global free trade. Stimulating regional trade blocs could, according to this line of reasoning, be a solution to end the (non-tariff) demand for protection, because members will be forced towards trade liberalization within the regional trade bloc.

Sir James Goldsmith, member of the European Parliament, advocates the formation of large regional trade blocs with open and free competition within each regional trade bloc. ${ }^{38}$ However, he also advocates restricted bilateral trade agreements with other regions. His arguments in favour of this policy prescription are based on the fear of competition from low-wage countries and the illusion that

37 Other regional blocks are the Central African Customs and Economic Union (UDAEC), the ASEAN Free Trade Area (AFTA), the Asia-Pacific Economic Cooperation Forum (APEC), the Gulf Cooperation Council (GCC), the Andean Pact and the Central American Common Market (CACM), European Free Trade Association (EFTA), in eastern and southern Africa, the Cross Border Initiative (CBI), and the South Asian Association for Regional Cooperation (SAARC). These are only a few of the more than sixty trade arrangements which can be identified (IMF, 1994, Vol. II, Appendix I). 38 Sir James's opinion is expressed in the interview Global Free Trade and GATT (1994). 
(p. 2): 'technology can be transferred instantaneously anywhere in the world on the back of a micro-chip.' Moreover, it relies heavily on the notion that balanced trade between a high-wage and a low-wage country is somehow detrimental to the high-wage country because (p. 4): "The number of people employed annually to produce one billion dollars worth of high tech products in the developed nations could be under 1,000. But the number of people employed in the low-cost areas to manufacture the products that we import would amount to tens of thousands of people.' This line of reasoning is based on the well-known fallacy of unequal exchange. According to this reasoning a lawyer who sells his legal advice for $\$ 300$ per hour is at a disadvantage when exchanging this one hour with a painter who paints his house in 10 hours and earns $\$ 30$ per hour. We, however, would rather be lawyers than painters.

At a more fundamental level this raises the question whether the formation of ever larger regional trading blocs is welfare increasing or welfare reducing. Krugman (1993) shows that a small number of regional trade blocs actually reduces global and regional welfare. His argument runs as follows.

Suppose the world is organized in $B$ identical trading blocs of equal economic size and with free trade within each bloc. Each bloc consists of more than one country and each bloc levies the 'optimal' tariff in a Nash equilibrium game, that is, given the tariff levels of the other trading blocs. The formation of fewer and therefore larger blocs leads to both trade creation and trade diversion. Trade creation, because the new members can participate in free trade within each bloc. Trade diversion, because larger blocs have more market power in the world, which increases the Nash equilibrium tariff. Furthermore, a higher tariff diverts trade that would otherwise take place between the blocs before integration took place. A smaller number of blocs thus has an ambiguous effect on economic welfare; a positive effect caused by trade creation and a negative effect caused by trade diversion. In this model welfare is of course maximized with only one global trading bloc. However, if the number of trading blocs exceeds a certain threshold level, a further increase in the number of trading blocks increases welfare; in this case the market power of each trading block is small and so is the corresponding Nash equilibrium tariff. In numerical examples Krugman (1993a) shows that the welfare minimizing number of blocs appears to be close to three.

This model is, of course, highly abstract and has been criticized for a number of reasons (see the discussion accompanying Krugman, 1993a). It is, for instance, likely that the trade creation aspect of the formation of trading blocs will dominate the trade diversion aspect, because blocs are usually formed by countries already trading a lot among themselves. These strong trade relations are often the reason to form a trade block in the first place. Moreover, experience over the past few decades does not indicate that in the formation of trading blocs, which leads to lower or abolished trade restrictions within the trading bloc, is on average accompanied by higher trade restrictions between the trading bloc and the outside world, as Krugman's analysis based on the 'optimal' tariff argument in a 
Nash equilibrium game would indicate. For example, the formation of the European Union has also reduced trade barriers with outsiders as the WTO (1995) has pointed out. The focal point of Krugman's analysis, however, is that trade blocs might harm welfare if they simultaneously create trade impediments between large trading blocs, as advocated by Sir James Goldsmith. Indeed, according to Krugman's analysis James Goldsmith's plan seems almost perfectly designed to minimize rather than maximize regional and global welfare.

\subsection{Power of Politics?}

As we noted above competition policies play an increasing role in the international game of protectionism. 'Unfair' trading practices by one trading bloc 'demand' retaliatory measures from another in order to open up the market of the first again. Some of Japan's trading partners, for example, have the perception that they are denied free access to the Japanese market. Although many frictions relating to competition policies have involved Japan, these types of frictions are present in all trading blocs (IMF, 1994, Vol. II). At the April 1994 Marrakesh meeting a number of countries expressed the view that competition policies should be included in WTO's future agenda. This issue takes us back to the famous question already posed by Adam Smith: would one renounce free trade for oneself if others did not embrace it too ${ }^{39}$ Thus, if one is involved in retaliatory measures the important question remains to what extent this will inflict harm on oneself and whether or not these measures will lead to the ultimate goal of global free trade.

Imposing protectionist measures may be beneficial in the short run for the imposing country under specific circumstances and in the absence of retaliation (for example due to a terms-of-trade effect). The short-run benefits may tempt countries, for example Japan, to actually impose protectionist measures. As has been extensively discussed in section 4 , however, imposing protectionist measures leads to (potentially) high costs in the long run. These costs largely arise from lagging productivity gains, such as invented intermediate or final goods not introduced on the market, a slower rate of quality improvement, a failure to benefit from economies of scale and scope, the inability to circumvent domestic bottleneck sectors, etc. Thus, the Japanese decision to heavily protect its domestic rice industry has not made the Japanese rice industry very efficient compared to other rice producing countries, at least not as efficient as it could have been in the absence of protection. On the contrary, the price of rice in Japan is 5 times the world price level. Similarly, the strong protection of the automobile, radio and television industries in the former Soviet Union has not led to products of modern design, nor to high quality or reliability. It has also not led to efficient production of these goods in the Soviet Union.

39 A short history of the various answers to this question can be found in Bhagwati (1993). 
The main concern of governments is the welfare level of their own citizens. Europe might consider the costs of protection imposed by Japan a problem between the Japanese government and the Japanese inhabitants if it would only lead to high costs for the Japanese society and not for the Europeans. However, this is not the case because Japanese protectionist measures also harm other countries due to lower gains from international trade. Thus, European citizens or interest groups demand some policy action from their government. European politicians, with a preference for dynamic actions and television coverage, might therefore be tempted to retaliate by imposing protectionist measures as well. This is a bad option in the long run for the exact same reasons as protectionism is bad for Japan in the long run.

Acknowledging that protection is bad in the long run, one might hope that temporary imposition of retaliatory measures might be beneficial if it quickly leads to the mutual abolishment of protectionist measures by Japan and Europe. This is the recent policy approach of the United States with respect to Japan and China. ${ }^{40}$ The important inherent danger of this approach is that this intentionally short-run policy can lead to long-run protection. Countries are not willing to concede that they were the first to impose 'unfair' trading practices. Indeed, usually all participants believe that actions on their part are necessary reactions to the unfair trading practices of others. Moreover, processes of escalating retaliation may also start to involve other sectors of the economy and other countries. For example, in the 1986 trade conflict with France, the United States deliberately threatened to target cheese imports from The Netherlands with a $100 \%$ import tariff. Although the power politics option seems to work in some cases it is not a viable structural solution due to the unpredictable outcome, the search for future revenge by the 'losers' and the inherent danger of escalating protection.

\subsection{Policy Advice}

We advocate a non-spectacular, but constructive policy in response to question 2 posed in the introduction: Europe should engage in continued multilateral trade negotiations strengthened by corporate diplomacy. Continued multilateral trade negotiations under supervision of the World Trade Organization and the formation of more or larger regional trade blocs will lead to more free trade, provided that barriers to trade with outsiders are also lifted (see subsection 6.1). For example, by effectuating the lowest possible outside barrier of the participating countries in a preferential trade agreement. Susan Strange (1995) notes that quiet corporate diplomacy is more effective in lifting trade barriers than power politics, in the

40 This action by the United States is beneficial only to Europe because both Japan and the United States will divert some of their trade from each other to Europe. As such, Europe is a free rider in the punishing strategy of the United States. Obviously, if Europe were to propose this as a structural solution to trade conflicts, Japan and the United States might not agree. 
case of Japan. For example, Coca Cola made a breakthrough in 1956 on the heavily protected Japanese market using firm-firm diplomacy by negotiating a bottling deal with Kirin, the biggest Japanese beer company. Furthermore, she notes (pp. 17-18) that firms are more successful because they seem to have a more friendly attitude and are more open-minded than government officials. Finally, we would like to recall that trade restrictions lead to very high costs for the imposing country over time. In this respect the following warning of The Economist (September 16, 1995, p. 33) should always be on the minds of trade politicians: 'Thinking of free trade as a concession to others, rather than a boon for one's own citizens, is a cardinal error in trade diplomacy.'

\section{SUMMARY AND CONCLUDING REMARKS}

The phrase 'a perfect model for an imperfect world' adequately described our initial findings in this paper. The static, perfect competition, constant returns to scale, factor endowment model of Heckscher, Ohlin, Samuelson and Vanek is of great analytical and graphical beauty. Unfortunately, this intellectually perfect model has limited explanatory power in an imperfect, dynamic world pervaded by economies of scale and scope, imperfect competition, knowledge spillovers, quality improvements, inventions of new varieties, etc. The paper argues that the very low estimated costs of protection in this perfect neo-classical model are misleading.

A wide range of models has been developed over the past two decades or so to address the real world issues mentioned above. They frequently rely on specific functional forms to get the main point across. In the details of predictions and policy prescriptions these models open up a Pandora's box of contradictions. Should one tax or subsidize the export sector in the absence of retaliation? The answer depends on the type of competition (quantity or price), other strategic variables (capacity), and timing (who moves first, second, third, etc.).

In an imperfect world politicians give in, at least to some extent, to the demands for protection from lobby groups, which can be either politically, income, employment, environmentally or ethically oriented. Our policy advice to Europe for cases when some of the players are not following the rules of the game which lead to free trade consists of three parts. ${ }^{41}$

First, in some exceptional cases countries adhering to the optimal outcome of free trade can indeed resort to 'tit for tat' strategies in trying to convince other players to follow the rules of the game. We do not advocate this as a structural solution.

Second, the slow but constructive process of multilateral trade negotiations, in practice often leading to regional trade blocs, is probably the most reliable road

41 We do not want to imply that Europe itself follows 'the rules of the game.' 
towards reaping the benefits of free trade. This process is enhanced by the effectiveness of quiet corporate diplomacy in reducing trade barriers.

Third, and most importantly, protectionist measures are too often used by all players involved. The last policy prescription follows from the seriously underestimated costs of protection in a dynamic world of imperfect competition. Shielding your producers from the cold winds of international competition over time deprives them of important technological breakthroughs in terms of variety extensions, quality improvements, knowledge spillovers, etc. This, in turn, reduces their competitiveness, resulting in a sliding scale of competitiveness by demanding more protection. In a dynamic world of imperfect competition and intra-industry trade the benefits of international trade are enormous. The stakes are simply too high to allow for extended periods of protection in almost any sector of the economy. The seriously underestimated costs associated with the political instruments of trade protection have tempted governments all over the world to excessively use protection. After all, it is easier to pull the trigger (impose protectionist measures) if you are involved in a game trying to shoot a beer can off a fence (representing the low estimated cost of protection) than if the gun is pointed at your head in a game of Russian roulette (representing the high actual costs of protection).

\section{APPENDICES}

\section{APPENDIX A}

Helpman (1987) derives a simple gravity model, with economies of scale, product differentiation and imperfect markets. Suppose there are two sectors in the economy, $X$ and $Y$ (the numéraire). Both sectors produce a large number of differentiated products with internal economies of scale under monopolistic competition. Free entry assures the absence of profits and determines the number of varieties. Let $X$ be the total production of $X$ at home and $x$ the amount of $X$ per variety. Foreign variables are indicated by an asterisk $\left(^{*}\right)$. Then the number of varieties equals:

$n=X / x$ (for the foreign country the expression is analogous).

Assuming identical homothetic preferences of the Dixit-Stiglitz type in both countries each variety will be consumed in the ratio of:

$$
s=G N P /\left(G N P+G N P^{*}\right) ; \text { thus } s^{*}=1-s .
$$

The value of exports of $X$ for the home country equals:

$$
s^{*} n x p=s^{*} X p
$$

$p$ is the price of $x$; (for $Y$ the equations are analogous) 
and for the foreign country

$$
s n^{*} x p=s X^{*} P \text {. }
$$

The total volume of trade, $V$, can be derived as follows:

$$
V=s\left(p X^{*}+Y^{*}\right)+s^{*}(p X+Y)=s G N P^{*}+s^{*} G N P=2 s G N P^{*} .
$$

The last step assumes equilibrium on the current account. This expression can be re-written as:

$$
V=2 s G N P^{*}=2 s s^{*}\left(G N P+G N P^{*}\right) \text {. }
$$

This expression is a basic variant of the gravity model and can be extended to incorporate more countries and inter-industry trade.

\section{APPENDIX B}

Data listings are too substantial to be presented here and are available from the authors upon request. A summary description of the data is given below.

Distances between countries are derived by assuming the world is a perfect sphere with a circumference of approx. $40,055 \mathrm{~km}$ and then by calculating the distance between capital cites on the basis of degrees latitude and longitude. The advantage is that with $k$ countries only $k$ data have to be gathered instead of $k(k-1) / 2$.

Bilateral trade data for 1992 and, in principle, 199 countries (resulting in a total of $199 \times 198$ bilateral trade flows) are taken into account. Since some entries are zero and some are not available only the positive bilateral trade flows are investigated. Finally, the largest subset for which all necessary data are available is used (leading to 5984 data entries).

Data for GDP are adjusted for purchasing power differences and are derived from the PENN World Tables 5.6. Tariff data are taken from the Barro-Lee data set and are own-import weighted tariff rates on intermediate inputs and capital goods (constructed from UNCTAD data). The Barro-Lee data are available from an anonymous ftp, address: NBER.HARVARD.EDU in the directory pub/barro.lee.

\section{REFERENCES}

Balassa, B. (1986), 'Intra-industry Specialization: A Cross-country Analysis,' European Economic Review, 30, pp. 27-42.

Balassa, B. (1976), 'Trade Creation and Diversion in the European Common Market: An Appraisal of the Evidence,' in: H. Glejser (ed.), Quantitative Studies of International Economic Relations, Amsterdam, North Holland.

Bergeijk, P.A.G. van (1994), Economic Diplomacy, Trade and Commercial Policy, Aldershot, Edward Elgar.

Bergeijk, P.A.G. van and C. van Marrewijk (1994), 'Economic Sanctions: A Hidden Cost of the New 
World Order,' in: M. Chatterji, H. Jager, and A. Rima (eds), The Economics of International Security, London, MacMillan, pp. 168-182.

Bhagwati, J. (1993), 'Fair Trade, Reciprocity, and Harmonization: The Novel Challenge to the Theory and Policy of Free Trade,' in: D. Salvatore(ed.), Protectionism and World Welfare, Cambridge, Cambridge University Press.

Bowen, H.P., E.E. Leamer and L. Sviekauskus (1987), 'Multicountry, Multifactor Tests of the Factor Abundance Theory,' American Economic Review, 77, pp. 402-414.

Brakman, S. (1991), International Trade Flow Modeling: Decomposition Analyses, Groningen, Wolters Noordhoff.

Brakman, S. and C.J. Jepma (1995), 'Protectionisme: politieke en economische aspecten,' Financiële en Monetaire Studies, Groningen, Wolters Noordhoff.

Brander, J.A. (1995), 'Strategic Trade Policy,' NBER Working Paper Series, No. 5020, Cambridge.

Brander, J.A. and B.J. Spencer (1985), 'Export Subsidies and International Market Share Rivalry,' Journal of International Economics, 16, pp. 83-100.

Dixit, A. and V. Norman (1980), Theory of International Trade, Cambridge, Cambridge University Press.

Dujat (1995), Success in Japan, Sassenheim, pp. 66-69 (in Dutch).

Emerson, M., D. Gros, A. Italianer, J. Pisani-Ferry, H. Reichenbach (1992), One Market, One Money, Oxford, Oxford University Press.

Ethier, W. (1982), 'National and International Returns to Scale in the Modern Theory of International Trade,' American Economic Review, 72, pp. 389-405.

Fase, M.M.G. (1985), 'The Statistical Properties of Glejser's Measure of Intra-industry Trade Specialisation,' Journal of International Economics, 28, pp. 375-382.

Fase, M.M.G. and C.C.A. Winder (1995), 'Produktie, werkgelegenheid en loonontwikkeling in Nederland: toetsing van de wetten van Verdoorn en Baumol,' De Nederlandsche Bank/Kwartaalbericht: Overige berichten, September 1995, pp. 11-25.

Feenstra, R.C. (1995), 'Estimating the Effects of Trade Policy,' NBER Working paper, No. 5051, Cambridge.

Greenaway, D. and D. Sapsford (1994), 'What does Liberalization do for Exports and Growth,' Welt Wirtschaftiches Archiv, 130, pp. 152-174.

Grossman, G.M. and E. Helpman (1991), Innovation and Growth in the Global Economy, MIT Press, Cambridge.

Grubel, H.G. and P.J. Lloyd (1975), Intra-industry Trade: The Theory and Measurement of International Trade in Differentiated Products, New York, John Wiley.

Grubel, H.G. and M. Walker (1989), Services Industry Growth, Vancouver, Fraser Institute.

Haaland, J.I. and V.D. Norman (1992), 'Global Production Effects of European Integration,' in: L.A. Winters (ed.), Trade Flows and Trade Policy after '1992', Cambridge, Cambridge University Press.

Harris, R.G. (1991), 'Symposium- The Canada-U.S. FTA: Economic Impact and Transition Effects,' Journal of Policy Modelling, 13, pp. 421-434.

Head, K., J. Ries and D. Swenson (1995), 'Agglomeration Benefits and Location Choice: Evidence from Japanese Manufacturing Investments in the United States,' Journal of International Economics, 38, pp. 223-247.

Helpman, E. (1987), 'Imperfect Competition and International Trade: Evidence from Fourteen Industrial Countries,' Journal of the Japanese and International Economics, 1, pp. 62-81.

Helpman, E. and P.R. Krugman (1985), Market Structure and Foreign Trade, Cambridge, MIT Press. Helpman, E. and P.R. Krugman (1989), Trade Policy and Market Structure, Cambridge, MIT Press. 
Hoekman, B.M. (1993), 'New Issues in the Uruguay Round and Beyond,' Economic Journal, 103, pp. 1528-1539.

Huber, J.R. (1971), 'Effect on Prices of Japan's Entry into World Commerce after 1858,' Journal of Political Economy, 79, pp. 614-628.

Hummels, D. and J. Levinsohn (1993), 'Monopolistic Competition and International Trade: Reconsidering the Evidence,' NBER Working Paper, No. 4389.

IMF (1994), 'International Trade Policies: The Uruguay Round and Beyond,' Volume I and II, World Economic and Financial Surveys, Washington.

Kremer, P. (1993), 'The O-ring Theory of Economic Development,' Quarterly Journal of Economics, pp. 551-575.

Krugman, P.R. (1979), 'Increasing Returns, Monopolistic Competition, and International Trade,' Journal of International Economics, 9, pp. 469-479.

Krugman, P.R. (1980), 'Scale Economies, Product Differentiation, and the Pattern of Trade,' American Economic Review, 70, pp. 950-959.

Krugman, P.R. (1991), 'Increasing Returns and Economic Geography,' Journal of Political Economy, 99 , pp. $483-499$.

Krugman, P.R. (1994), 'Competitiveness; A Dangerous Obsession,' Foreign Affairs, March/April, pp. 28-44.

Krugman, P.R. (1993a), 'Regionalism versus Multilateralism: Analytic Notes,' in: J. de Melo and A. Panagariya (eds.), New Dimensions in Regional Integration, Cambridge, Cambridge University Press.

Krugman, P.R., and R.Z. Lawrence (1993b), 'Trade, Jobs and Wages,' NBER Working Paper, No. 4478 , Cambridge.

Leamer, E.E. (1984), Sources of International Comparative Advantage: Theory and Evidence, Cambridge, MIT Press.

Leamer, E.E. (1994), 'Testing Trade Theory,' in: D. Greenaway and L.A. Winters (eds.), Surveys in International Trade, Oxford, Basil Blackwell.

Leamer, E.E. (1995), The Heckscher-Ohlin Model in Theory and Practice, Princeton Studies in International Finance No. 77, Princeton, New Jersey.

Magee, S.P., W.A. Brock and L. Young (1989), 'Black Hole Tariffs and Endogenous Policy Theory: Political Economy in General Equilibrium,' Cambridge, Cambridge University Press.

Markheim, D. (1994), 'A Note on Predicting the Trade Effects of Economic Integration and Other Preferential Trade Agreements: An Assessment,' Journal of Common Market Studies, 32, pp. 103110.

Markusen, J.R. (1986), 'Explaining the Volume of Trade: An Eclectic Approach,' American Economic Review, 76, pp. 1002-1011.

Markusen, J.R. (1989), 'Trade in Producer Services and in Other Specialized Intermediate Inputs,' American Economic Review, 79, pp. 85-95.

Markusen, J.R., J.R. Melvin, W.H. Melvin, W.H. Kaempfer, and K.E. Maskus (1995), International Trade: Theory and Evidence, New York, McGraw-Hill.

Marrewijk, C. van, J. Stibora and A. de Vaal (1996), 'Services Tradeability, Trade Liberalization, and Foreign Direct Investment,' forthcoming in Economica.

Miller, M.H. and J.E. Spencer (1977), 'The Static Economic Effect of the UK Joining the EEC: A General Equilibrium Approach,' Review of Economic Studies, 44, pp. 71-94.

Ministerie van Economische Zaken (1994), De GATT Uruguay Ronde: resultaten en gevolgen, Den Haag. 
OECD (1992), Industrial Policy in OECD Countries, Annual Review 1992, Part 4, OECD, Paris, pp. $167-191$.

OECD (1993), Industrial Policy in OECD Countries, Annual Review 1993, OECD, Paris.

Pilat, D. (1993), The Economics of Catch-up: The Experience of Japan and South Korea, Dissertation, Groningen.

Richardson, J.D. (1988), 'Empirical Research on Trade Liberalisation with Imperfect Competition: A Survey,' OECD Working Paper, No. 58.

Rivera-Batiz, L. and P. Romer (1991), 'International Trade with Endogenous Technological Change,' European Economic Review, 35, pp. 971-1004.

Rivera-Batiz, L. and P. Romer (1991b), 'Economic Integration and Endogenous Growth,' Quarterly Journal of Economics, 106, pp. 531-556.

Romer, P. (1994), 'New Goods, Old Theory, and the Welfare Costs of Trade Restrictions,' Journal of Development Economics, 43, pp. 5-38.

Sach, J. and A. Warner (1995), 'Economic Reform and the Process of Global Integration,' Brookings Papers on Economic Activity, 1, pp. 1-118.

Sazanami, Y., S. Urata and H. Kawai (1995), Measuring the Costs of Protection in Japan, Washington, Institute for International Economics.

Solow, R.M. (1994), 'Perspectives on Growth Theory,' Journal of Economic Perspectives, 8, pp. 4554.

Spencer, B.J. and J.A. Brander (1983), 'International R\&D Rivalry and Industrial Strategy,' Review of Economic Studies, 50, pp. 707-722.

Strange, S. (1995), 'European Business in Japan: A Policy Crossroads?', Journal of Common Market Studies, 33, pp. 1-25.

Tybout, J.R. (1993), 'Internal Returns to Scale as a Source of Comparative Advantage: The Evidence,' American Economic Review Papers and Proceedings, 83, pp. 440-444.

UNCTAD (1993), World Investment Report, Geneva.

UNCTAD and World Bank (1994), Liberalizing International Transactions in Services, United Nations, Geneva.

Winters, L.A. (1993), 'The European Community: A Case of Successful Integration?,' in: J. de Melo and A. Panagariya (eds.), New Dimensions in Regional Integration, Cambridge, Cambridge University Press.

World Trade Organization (1995), Regionalism and the World Trading System, Geneva.

Zwet, A. van der (1995), Enige effecten van globalisering op de Nederlandse economie, DNB-MEB Serie, No. 1995-96, Amsterdam.

\section{Summary}

\section{TRADE POLICY UNDER IMPERFECT COMPETITION: THE ECONOMICS OF RUSSIAN ROULETTE}

Neo-classical economic theory shows that managed trade or protectionism is (almost) always welfare decreasing. However, measurements of the welfare costs of protectionism based on neo-classical models seem to suggest that these costs are quite small. We discuss general new insights and developments in the theory, policy and empiricism of international trade. The observation that intra-industry trade and the services sector are important has led to a shift in theory away from constant returns to 
scale and perfect competition towards economies of scale and scope, externalities, market imperfections, and imperfect competition. Although this, in principle, opens the door to beneficial government intervention in the economic process, we emphasize that the true costs of protection can potentially be much higher than is generally acknowledged as a result of the above mentioned shift. 